\title{
KRITIČKO MIŠLJENJE U OBRAZOVANJU: DOSADAŠNJI DOPRINOSI I OTVORENI SMJEROVI
}

\author{
Iva Buchberger, Valentina Bolčević, Vesna Kovač
}

Filozofski fakultet Sveučilišta u Rijeci

Rijeka, Hrvatska

ibuchberger@ffri.hr

vbolcevic@ffri.hr

vkovac@ffri.hr

Primljeno: 21. 6. 2017.

\begin{abstract}
U ovome radu razmatraju se i prikazuju dosadašnje spoznaje o kritičkom mišljenju u području obrazovanja. Svrha rada je prikaz i analiza dosadašnjih znanstvenih doprinosa istraživanja kritičkog mišljenja u obrazovanju kako bi se izradila teorijska podloga i identificirali inovativni pravci budućih istraživanja tog područja. Rad donosi pregled i komentar na određenje koncepta kritičkog mišljenja te prikaz značajnih istraživanja područja kritičkog mišljenja u obrazovanju unutar stranog i hrvatskog istraživačkog konteksta. Nalazi dosadašnjih istraživanja upućuju na važnost razvoja i implementacije poučavanja za kritičko mišljenje s obzirom da ono pospješuje kvalitetu procesa učenja i poučavanja u nastavi. Istraživanja pokazuju da nastavnik ima ključnu ulogu u poticanju razvoja kritičkog mišljenja učenika prije svega kroz primjenu metoda aktivnog učenja i poučavanja. U zaključnom dijelu rada, na temelju određenja koncepta kritičkog mišljenja i prikaza dosadašnjih istraživanja, razvija se konstrukt poučavanja za kritičko mišljenje kroz njegovu kategorizaciju i operacionalizaciju koje ujedno predstavljaju moguće pravce budućih istraživanja.
\end{abstract}

Ključne riječi: kritičko mišljenje, nastavnici, obrazovanje, poučavanje za kritičko mišljenje, učenici

\section{Uvod}

Obrazovna politika, struka i znanost jednoglasni su u isticanju važnosti kritičkog mišljenja i zalaganja za razvoj obrazovanja utemeljenog na aktivnom učenju i poučavanju. Različite utjecajne zajednice i or- 
ganizacije koje djeluju na globalnoj razini (primjerice Europska unija, OECD, UNESCO, UNICEF i dr.) u svojim policy dokumentima i publikacijama jasno ističu da je poučavanje za kritičko mišljenje jedan od ciljeva kojemu stremi suvremeno obrazovanje i demokratsko društvo u cjelini. U Pariškoj deklaraciji (CEU, 2015) ministara obrazovanja Europske unije kao jedan od ciljeva na razini europskih nacionalnih obrazovnih politika navodi se razvoj kritičkog mišljenja građana kao jednu od mjera prevladavanja diskriminacije i indoktrinacije u društvu. Nadalje, u Zaključku Vijeća Europske unije o razvoju medijske pismenosti i kritičkog mišljenja (CEU, 2016) države članice također se poziva da obrate pažnju i otvore prostor za kritičko mišljenje u obrazovanju. U publikacijama OECD-a (Hoidin i Kärkkäinen, 2014; Kärkkäinen, 2012) kritičko mišljenje se uz tehničke i socijalne vještine izdvaja kao jedna od ključnih vještina obrazovanja 21. stoljeća te sastavni dio kurikulumskih inovacija suvremenih obrazovnih sustava. U dokumentu međunarodne mreže podataka o odgojno-obrazovnim sustavima koji uključuje pregled odluka o pojedinim pitanjima obrazovnih politika europskih zemalja (EC, EACEA i Eurydice, 2016) uočava se da je znatan broj zemalja implementirao odluke obrazovne politike koje su usmjerene na poučavanje za kritičko mišljenje. Navedeno upućuje na zaključak da se zalaganje za različite moduse implementacije razvijanja kompetencije kritičkog mišljenja prepoznaje kao značajna smjernica obrazovne politike europskih zemalja te da su smjerovi razvoja europskih obrazovnih politika na razini pojedinih tijela Europske unije okrenuti prema obrazovanju u kojemu se nastoji poticati i osnažiti razvoj kritičkog mišljenja.

Razvojne smjernice za obrazovanje i znanost u Republici Hrvatskoj prate navedeno policy usmjerenje europskih obrazovnih politika. To se uočava u najnovijem i najrelevantnijem policy dokumentu Republike Hrvatske Strategiji obrazovanja, znanosti i tehnologije (MZOS, 2015). U Strategiji se prije svega ističe provedba cjelovite kurikularne reforme koja je dominanto usmjerena na razvoj temeljnih kompetencija za cjeloživotno učenje uz jasno definirane odgojno-obrazovne ishode različitih razina postignuća (od razumijevanja do vrednovanja). Spomenuti odgojno-obrazovni ishodi upravo se ostvaruju razvojem kreativnosti, inovativnosti, inicijativnosti, odgovornosti i konačno razvojem kritičkog mišljenja. Istaknute preporuke obrazovne politike o važnosti razvoja kritičkog mišljenja u obrazovanju podupiru i dosadašnja znanstvena i stručna saznanja. U teorijskim razmatranjima izrijekom se navodi kako je kritičko mišljenje jedan od najvažnijih, ali i najizazovnijih ishoda 
dobrog poučavanja (Grozdanić, 2009). Spominje se da je obrazovanje dominantan prostor primjene i razvoja kritičkog mišljenja te da obrazovni proces ne treba primarno biti sveden na učenje tehničkih znanja, već bi bilo poželjno da njegova primarna uloga bude upravo poučavanje kritičkog mišljenja (Bošnjak, 2009). Nerijetko se kritičko mišljenje smatra i središnjim ishodom učenja, posebice u visokoškolskoj nastavi, što se može iščitati iz strategija sveučilišta, akreditacijskih standarda i različitih policy dokumenata nacionalnih obrazovnih politika (Facione et al., 1995). Pešić (2003) navodi kako uključivanje kritičkog mišljenja u obrazovnu praksu predstavlja težnju suvremenih obrazovnih sustava, a ta se tendencija uočava kao dio i obrazovnih reformi u nerazvijenim zemljama. Istraživanja kritičkog mišljenja u obrazovanju pokazala su da se vještine kritičkog mišljenja uspješno mogu primijeniti u različitim segmentima života pojedinca, čime se nadilazi njihovo korištenje isključivo unutar učionice (Anderson i Reid, 2013). S obzirom na značajnu ulogu kritičkog mišljenja u obrazovanju, važno je promišljati i o samom okruženju u kojemu se odvija proces poučavanja učenika kako bi se osigurali uvjeti koji pogoduju razvoju kritičkog mišljenja, odnosno kako bi se u nastavu uspješno integriralo poučavanje za kritičko mišljenje.

U ovom se radu razmatraju i prikazuju dosadašnje spoznaje o kritičkom mišljenju u području obrazovanja. Svrha ovoga rada je prikaz i analiza dosadašnjih znanstvenih doprinosa autora koji su istraživali područje kritičkog mišljenja u obrazovanju kako bi se izradila teorijska podloga i identificirali inovativni pravci budućih istraživanja tog područja. Rad donosi pregled i komentar na određenje koncepta kritičkog mišljenja te prikaz značajnih istraživanja područja kritičkog mišljenja u obrazovanju unutar stranog i hrvatskog istraživačkog konteksta. Nalazi dosadašnjih istraživanja upućuju na važnost razvoja i implementacije poučavanja za kritičko mišljenje budući da ono pospješuje kvalitetu procesa učenja i poučavanja u nastavi. Kritičko mišljenje doprinosi višim razinama usvojenosti i razumijevanja nastavnog sadržaja, pomaže učenicima da lakše prate nastavni sadržaj i da ga kritički vrednuju, pospješuje razvoj samoreguliranog učenja, potiče samoevaluaciju procesa učenja te od učenika zahtijeva samostalnost u donošenju zaključaka, što u konačnici dovodi do težeg zaboravljanja postignutog znanja. Istraživanja pokazuju da nastavnik ima ključnu ulogu u poticanju razvoja kritičkog mišljenja učenika kroz primjenu metoda i oblika rada aktivnog učenja i poučavanja te drugih aktivnosti u nastavi poput postavljanja 
izazovnih pitanja i uvažavanja stila mišljenja učenika. U zaključnom dijelu rada na temelju određenja koncepta kritičkog mišljenja i prikaza dosadašnjih istraživanja razvija se konstrukt poučavanja za kritičko mišljenje kroz njegovu kategorizaciju i operacionalizaciju koje ujedno predstavljaju moguće pravce budućih istraživanja.

\section{Određenje kritičkog mišljenja}

Rasprave o kritičkom mišljenju nerijetko sadrže teze o njegovoj konceptualnoj složenosti i različitim određenjima (Buchberger, 2012; Klooster, 2002; Pešić, 2003). Usprkos tome, postignuta je suglasnost oko temeljnih odrednica kritičkog mišljenja i opisa kompetencija na koje se ono odnosi. Prije određenja kritičkog mišljenja za potrebe ovoga rada, važno je istaknuti saznanja najrelevantnijih autora koji su uvelike doprinijeli razvoju koncepta kritičkog mišljenja (usp. Buchberger 2012).

Prvi predstavnik modernog kritičkog mišljenja John Dewey (2012) određuje kritičko mišljenje kao aktivno, ustrajno i temeljito propitivanje vjerovanja uz razmatranje onih postavki, osnova i dokaza koje podupiru to vjerovanje. Autor kritičko mišljenje naziva refleksivnim i uspoređuje ga s običnim mišljenjem kojem pripisuje prihvaćanje vjerovanja utemeljenog na malo ili gotovo niti jednom dokazu. Nadalje, istaknuti suvremeni teoretičar kritičkog mišljenja Robert H. Ennis (2011) određuje kritičko mišljenje kao proces odlučivanja u što vjerovati ili što učiniti. Autor ističe kako kritičko mišljenje uključuje vrijednosti intelektualnog poštenja i otvorenosti, autonomije i samokritičnosti, predanosti istini i osjetljivosti na kontekst. Pritom naglašava vještine razlikovanja činjenica i vrijednosti, razlikovanja eksplicitnih i implicitnih pretpostavki, razlikovanja argumentiranih i neargumentiranih tvrdnji, prepoznavanje grešaka u zaključivanju i određivanje snage argumenata. Najpoznatiji suvremeni teoretičar kritičkog mišljenja kao odgojno-obrazovnog fenomena Matthew Lipman (2002) određuje kritičko mišljenje, nazivajući ga također refleksivnim, kao proces prosuđivanja utemeljenog na kvalitetnom vrednovanju alternativa s obzirom na dostupne argumente.

Kritičko mišljenje dodatno se određuje kroz razradu kompetencija (odnosno vještina) koje uključuje. Primjerice, Facione (1990) određuje kritičko mišljenje kroz šest ključnih vještina - interpretaciju, analizu, evaluaciju, inferenciju, objašnjavanje i samoregulaciju koje su elaborirane u Tablici 1 . 
Tablica 1. Određenje kritičkog mišljenja kroz šest ključnih vještina (prema Facione, 1990)

\begin{tabular}{|l|}
\hline \multicolumn{1}{|c|}{ Vještine kritičkog mišljenja } \\
\hline $\begin{array}{l}\text { Interpretacija: razumijevanje značenja kroz procese kategorizacije, dekodiranja } \\
\text { i objašnjavanja. }\end{array}$ \\
\hline $\begin{array}{l}\text { Analiza: identificiranje odnosa koncepata, tvrdnji i pitanja kroz procese definira- } \\
\text { nja i uspoređivanja termina (pojmova) te prepoznavanja i analize argumenata. }\end{array}$ \\
\hline $\begin{array}{l}\text { Evaluacija: procjenjivanje opravdanosti tvrdnji, kontekstualne važnosti onoga } \\
\text { što se zastupa i valjanosti argumenata. Postavljanje pitanja te formiranje protu- } \\
\text { argumenata (prigovora) prema onome što se zastupa. }\end{array}$ \\
\hline $\begin{array}{l}\text { Inferencija: prepoznavanje pretpostavki koje zahtijevaju opravdanje (dokaze), } \\
\text { prepoznavanje relevantnih informacija, formiranje različitih alternativi za rješa- } \\
\text { vanje problema, izvođenja opravdanih zaključaka. }\end{array}$ \\
\hline $\begin{array}{l}\text { Objašnjavanje: iznošenje i predstavljanje rezultata promišljanja o određenoj temi } \\
\text { i načina kako se došlo do tih rezultata s posebnim fokusom na predstavljanje } \\
\text { argumenata. }\end{array}$ \\
\hline $\begin{array}{l}\text { Samoregulacija: samoevaluacija procesa zaključivanja uz ispravljanje vlastitih } \\
\text { pogrešaka u zaključivanju. }\end{array}$ \\
\hline
\end{tabular}

Iz prikaza navedenih vještina kritičkog mišljenja može se uočiti kako kritičko mišljenje uključuje više razine mišljenja počevši od razumijevanja i interpretacije informacija, preko argumentiranja i vrednovanja, do metarazine procjenjivanja vlastitih procesa zaključivanja uz sposobnost reguliranja i ispravljanja vlastitih pogrešaka u zaključivanju. U tom smislu razvoj vještina kritičkog mišljenja doprinosi ostvarivanju svih obrazovnih postignuća od poznavanja i razumijevanja nastavnog sadržaja, preko primjene i analize, do vrednovanja i stvaranja (Anderson i Krathwohl, 2001).

Temeljem prikazanih definicija kritičkog mišljenja u tekstu koji slijedi izdvajaju se i sistematiziraju temeljni elementi kritičkog mišljenja sa ciljem njegova određenja kao podloge za razvijanje temeljnog konstrukta poučavanja za kritičko mišljenje. Kritičko mišljenje složeni je proces i rezultat (a) razumijevanja i interpretacije informacija; (b) analize i (c) vrednovanja informacija; (d) uspoređivanja s drugim informacijama i generiranja prigovora; te (e) konačno zauzimanja stava uz (f) izraženu samoregulaciju zaključivanja (usp. Buchberger, 2012). Uz to, kritičko mišljenje uključuje različiti spektar kompetencija koje se mogu sažeti na sljedeći način (Tablica 2). 
Tablica 2. Kompetencije kritičkog mišljenja

\begin{tabular}{|c|}
\hline Kompetencije kritičkog mišljenja \\
\hline $\begin{array}{l}\text { Razumijevanje i interpretacija: razumijevanje značenja koncepata i informacija; } \\
\text { kategorizacija informacija; objašnjavanje informacija vlastitim riječima; navo- } \\
\text { đenje primjera. }\end{array}$ \\
\hline $\begin{array}{l}\text { Analiza: određenje odnosa među pojmovima, informacijama i gledištima; razli- } \\
\text { kovanje relevantnih i irelevantnih informacija unutar zadanog konteksta; defini- } \\
\text { ranje koncepata; prepoznavanje argumenata i njegovih sastavnih dijelova (premi- } \\
\text { sa i zaključnih sudova); razlikovanje činjenica i vrijednosti. }\end{array}$ \\
\hline $\begin{array}{l}\text { Vrednovanje: razlikovanje opravdanih i neopravdanih tvrdnji; vrednovanje alter- } \\
\text { nativa s obzirom na raspoloživa opravdanja i objašnjenja; vrednovanje informa- } \\
\text { cija i gledišta: propitivanje pretpostavki iz kojih proizlaze određene informacije; } \\
\text { razlikovanje implicitnih i eksplicitnih pretpostavki. }\end{array}$ \\
\hline $\begin{array}{l}\text { Uspoređivanje i generiranje prigovora: povezivanje prethodnog znanja i novih } \\
\text { informacija; povezivanje različitih informacija iz različitih područja; sagledava- } \\
\text { nje informacija iz različitih gledišta; uočavanje nedostataka određenih gledišta; } \\
\text { formiranje prigovora u obliku protuargumenata, navođenjem protuprimjera i sl. }\end{array}$ \\
\hline $\begin{array}{l}\text { Zauzimanje stavova: formiranje stavova i zastupanja ideja; opravdavanje stavova } \\
\text { i gledišta; preuzimanje aktivne uloge u procesu zaključivanja; sinteza informaci- } \\
\text { ja i organizacija sadržaja u smislenu cjelinu. }\end{array}$ \\
\hline $\begin{array}{l}\text { Samoregulacija zaključivanja: nadgledanje i procjenjivanje vlastitog razumije- } \\
\text { vanja informacija i zaključivanja; ispravljanje vlastitih pogrešaka u zaključiva- } \\
\text { nju; usmjeravanje vlastita mišljenja k ispravnosti. }\end{array}$ \\
\hline
\end{tabular}

Nakon određenja koncepta kritičkog mišljenja uz prikaz njegovih ključnih kompetencija daje se prikaz i analiza dosadašnjih relevantnih i recentnih znanstvenih istraživanja područja kritičkog mišljenja u obrazovanju u kojima se posebice ističe važnost njegova razvoja u odgojno-obrazovnom kontekstu. Izdvajaju se indikativni rezultati pojedinih istraživanja kritičkog mišljenja u obrazovanju unutar stranog i hrvatskog istraživačkog konteksta na temelju kojih se kasnije u radu razrađuje teorijska podloga konstrukta poučavanja za kritičko mišljenje i identificiraju inovativni pravci za provođenje budućih istraživanja u tom području.

\section{Važnost razvoja kritičkog mišljenja u obrazovanju: dosadašnja istraživanja}

Važnost razvoja kritičkog mišljenja u suvremenom kontekstu proizlazi iz zahtjeva za demokratizacijom društva koja podrazumijeva aktiv- 
ne građane koji promišljaju, preispituju, vrednuju i donose odluke. Uz to, razvidan tehnološki napredak društva kojeg prate stalne i brze promjene te širenje korpusa dostupnih informacija idu u prilog zalaganju za razvoj kritičkog mišljenja (Buchberger, 2012). Ipak, kritičko mišljenje ne treba promatrati samo kao odgovor na potrebe suvremenog društva nego kao i misiju obrazovanja. Naime, istraživanja pokazuju kako pristup obrazovanju u čijoj je osnovi kritičko mišljenje doprinosi razvoju učenja i poučavanja koji kao rezultat donose dugotrajnije, dublje, uporabnije, pa samim time i vrjednije znanje (Nikčević-Milković, 2004).

\subsection{Kritičko mišljenje u obrazovanju: pregled dosadašnjih istraživanja u stranom kontekstu}

U prilog važnosti razvoja kritičkog mišljenja u obrazovanju govore istraživanja stranih autora u kojima se ispitivala povezanost različitih aspekata kritičkog mišljenja i ključnih dionika odgojno-obrazovnog sustava. U okviru toga, može se istaknuti nekoliko skupina istraživanja koja problematiziraju navedene aspekte. Prva skupina istraživanja usmjerena je na ispitivanje povezanosti pojedinih obilježja nastavnika i kritičkog mišljenja (Boonjeam, Tesaputa i Sri-ampai, 2017; Chee Choy i San Oo, 2012; Emir, 2013; Innabi, 2003; Moeti, Mgawi i Smitta Moalosi, 2017; Warburton i Toff, 2005). Drugu skupinu čine istraživanja koja se fokusiraju na odnos didaktičko-metodičkog aspekta nastave i kritičkog mišljenja, što se odnosi na nastavne metode i aktivnosti koje uključuju aktivan pristup učenika u nastavi (Fung, 2014; Lewine et al., 2015; Piergiovanni, 2014; Razei, Derakshan i Bagherkazemi, 2011; Shim i Walczak, 2012; Tiruneh, Verburgh i Elen 2014). Uz navedeno, izdvaja se i treća skupina istraživanja povezanih s pristupima poučavanju kritičkog mišljenja gdje se prati rasprava autora o izravnom poučavanju vještinama kritičkog mišljenja u nastavi (Alwehaibi, 2012; Cotter, 2009; Wallace i Jefferson, 2015; Marin i Halpern, 2011).

Neke od tema vezanih uz područje kritičkog mišljenja u obrazovanju koje su strani autori također proučavali su transverzalnost vještina kritičkog mišljenja kroz različite nastavne predmete (Anderson i Reid, 2013), razvoj dispozicija kritičkog mišljenja u nastavi (Ordem, 2017), 
povezanost različitih stilova učenja s kritičkim mišljenjem (Gyeong i Myung, 2008) ${ }^{1}$ te razlike u definiranju i razumijevanju kritičkoga mišljenja nastavnika i studenata (Ahern et al., 2012; Bahr, 2010). Pritom se uočava kako su spomenuta istraživanja dominantno usmjerena na razinu visokog obrazovanja, dok istraživanja na razini srednjeg i osnovnog obrazovanja izostaju. Uz to, primjetan je i nedostatak istraživanja koja proučavaju povezanost kritičkog mišljenja s pojedinim aspektima obrazovnog procesa poput školskog uspjeha učenika te aspektima nastave kao što su razina usvojenosti i razumijevanja nastavnog sadržaja te interdisciplinarno povezivanje nastavnog sadržaja različitih nastavnih predmeta, što predstavlja potencijalno značajan indikator važnosti razvoja kritičkog mišljenja u obrazovanju. U nastavku teksta prikazat će se rezultati nekih od dosadašnjih istraživanja stranih autora koja nose indikativne zaključke koji govore u prilog važnosti zalaganja za razvoj kritičkog mišljenja u obrazovanju.

Emir (2013) je proveo istraživanje s namjerom ispitivanja postojanja povezanosti između stilova mišljenja nastavnika i dispozicija za kritičko mišljenje. Rezultati istraživanja pokazali su da postoji pozitivna povezanost između pojedinih stilova mišljenja nastavnika te određenih dispozicija za kritičko mišljenje. Pozitivna povezanost pronađena je između sistematičnosti i prosudbenog stila mišljenja, sklonosti prema traganju za istinom te holističkog i izvršnog stila mišljenja, kao i između otvorenosti za nove ideje te holističkog i prosudbenog stila mišljenja. Autor zaključuje da ovi rezultati imaju značajan efekt u odgojnoobrazovnoj praksi kada je riječ o razvoju kritičkog mišljenja učenika. Naime, stil mišljenja nastavnika povezan je s njegovim odlukama $u$ kreiranju nastavnog procesa koji kao takav potiče ili inhibira razvoj kritičkog mišljenja učenika. Isto tako, za razvoj kritičkog mišljenja učenika važno je da nastavnici učenicima dopuste koristiti se vlastitim stilom mišljenja te da ih vrednuju iz različitih perspektiva ovisno o njihovom stilu mišljenja.

Warburton i Toff (2005) proveli su istraživanje usmjereno na ispitivanje stavova nastavnika o učinkovitosti primjene aktivnosti u nastavi koje potiču razvoj kritičkog mišljenja kod različitih skupina studenata

\footnotetext{
${ }^{1}$ Gyeong i Myung (2008) u svojem su radu istraživali povezanost kritičkog mišljenja s divergentnim, konvergentnim, akomodacijskim i asimilacijskim stilom učenja koji se temelje na Kolbovom inventaru stilova učenja.
} 
s obzirom na njihovo akademsko postignuće. Pokazalo se da nastavnici vjeruju da su nastavne aktivnosti koje (u višoj ili nižoj mjeri) potiču razvoj kritičkog mišljenja studenata učinkovitije kod studenata koji pokazuju bolje akademsko postignuće za razliku od onih s nižim akademskim postignućem. Shodno tome, spomenuti stavovi nastavnika imaju za posljedicu izostanak primjene aktivnosti u nastavi usmjerenih na razvoj kritičkog mišljenja spram onih studenata koji iskazuju slabije akademsko postignuće. Autori tvrde da takav rezultat upućuje na zaključak kako izostanak aktivnosti kojima se potiče kritičko mišljenje studenata slabijeg akademskog postignuća u konačnici i rezultira slabijim akademskim postignućem.

Innabi (2003) je među nastavnicima matematike istražio koji se aspekti kritičkog mišljenja mogu uočiti tijekom njihovog predavanja i u kojoj mjeri ti aspekti dominiraju nastavom. Istraživanje je pokazalo da poučavanje nastavnika, gledajući na općenitoj razini, nije bilo usmjereno na razvoj kritičkog mišljenja kroz nastavni sadržaj, odnosno da nastavnici nisu bili orijentirani na poticanje razvoja kritičkog mišljenja studenata. Autor smatra da je ovakav rezultat posljedica toga što nastavnici ne percipiraju kritičko mišljenje kao primarni cilj nastave koji bi kao takav trebao voditi drugim ciljevima, nemaju dovoljno znanja o kritičkom mišljenju, kao i strategijama razvoja kritičkog mišljenja učenika kroz nastavni sadržaj te iz razloga što je poučavanje nastavnika često pod utjecajem državnog kurikuluma koji ne prepoznaje razvoj kritičkog mišljenja učenika kao važan ishod procesa poučavanja. $^{2}$

$\mathrm{Na}$ temelju prikazanih rezultata istraživanja koji uključuju različite aspekte povezanosti određenih obilježja nastavnika i kritičkog mišljenja (poput povezanosti stila mišljenja, odnosno stavova nastavnika s njihovim dispozicijama za kritičko mišljenje, odnosno kompetencijama primjene kritičkog mišljenja u nastavi) moguće je izdvojiti nekoliko smjernica koje naglašavaju neke aspekte važne uloge nastavnika u razvijanju kritičkog mišljenja učenika (Tablica 3).

${ }^{2}$ Innabi (2003) je proveo istraživanje u srednjim školama u Jordanu. Istraživanje je temeljio na dvjema pretpostavkama: 1) kritičko mišljenje temeljni je cilj obrazovanja u Jordanu; 2) ponašanje nastavnika najvažniji je čimbenik koji utječe na razvoj kritičkog mišljenja kod učenika. 
Tablica 3. Uloga nastavnika u razvijanju kritičkog mišljenja učenika

Razvijene kompetencije kritičkog mišljenja nastavnika: potrebno je da nastavnici posjeduju znanja o konceptu kritičkog mišljenja i kompetencijama koje ono uključuje; potrebno je da su nastavnici osposobljeni za osmišljavanje i primjenu različitih nastavnih strategija, nastavnih metoda i oblika rada koji doprinose razvoju kritičkog mišljenja učenika.

Kritičko mišljenje kao cilj poučavanja: važno je da razvoj kritičkog mišljenja učenika bude u fokusu učenja i poučavanja, odnosno da je jasno istaknut kao jedan od ciljeva poučavanja.

Uključenost i uvažavanje svih učenika: za razvoj kritičkog mišljenja učenika preporuča se da nastavnici uvažavaju različite stilove mišljenja učenika; preporuča se da nastavnici u aktivnosti kojima se pospješuje razvoj kritičkog mišljenja uključuju učenike različitih sposobnosti i postignuća.

Odgovornost $i$ značajna uloga nastavnika: nastavnik ima značajnu ulogu u poticanju kritičkog mišljenja učenika te odgovornost u kreiranju okruženja koje će pridonijeti razvoju vještina kritičkog mišljenja učenika.

Nadalje, Shim i Walczak (2012) proučavali su povezanost različitih praksi poučavanja koje uključuju usmjereno vođenje studenata i razvoj sposobnosti kritičkog mišljenja. Značajan je rezultat ovog istraživanja taj da postavljanje izazovnih pitanja studentima tijekom nastave najviše pridonosi razvoju njihova kritičkog mišljenja. Marin i Halpern (2011) istraživali su mogu li se vještine kritičkog mišljenja naučiti, prakticirati te prenijeti ukoliko ih se izravno poučava (via explicit instruction). Pokazalo se da je izravno poučavanje studenata vještinama kritičkog mišljenja u nastavi učinkovitije u odnosu na druge pristupe u njegovu poučavanju.

Pitanjem pospješuje li se u nastavi razvoj vještina kritičkog mišljenja studenata kada im se daju izravne upute bavili su se također Wallace i Jefferson (2015) koji su ispitivali razlike između dvije skupine studenata, gdje je jedna skupina studenata koristila priručnik za uvježbavanje i razvoj vještina kritičkog mišljenja tijekom rješavanja problema postavljenih na nastavi. Skupina studenata koja je koristila priručnik pokazala je bolje rezultate na testu mjerenja vještina kritičkog mišljenja u odnosu na skupinu studenata koja nije koristila priručnik. Dodatno, istraživanja su pokazala da uspješnom razvoju kritičkog mišljenja učenika u nastavi pogoduju suradnički oblici rada među učenicima te metode rada i aktivnosti u nastavi koje podrazumijevaju aktivan pristup učenika u procesu poučavanja poput diskusije, debate, studije slučaja, 
problemskih zadataka, zadataka esejskog tipa, kao i refleksija učenika na vlastiti učinak u nastavi (Piergiovanni, 2014; Razei, Derakshan i Bagherkazemi, 2011). Shodno rezultatima prikazanih istraživanja, za razvoj kritičkog mišljenja učenika u nastavi poželjno je da proces poučavanja obuhvaća one aktivnosti koje će uključivati različite metode aktivnog učenja i poučavanja. Uz to, za uspješnije poučavanje vještinama kritičkog mišljenja nastavnicima se preporuča da učenike izravno poučavaju tim vještinama.

U raspravi o važnosti kritičkog mišljenja u obrazovanju u stranom istraživačkom kontekstu potrebno je dodatno izdvojiti i sljedeće preporuke stranih autora (Bassham et al., 2008; Da Silva Almeida i Rodrigues Franco, 2011; Paul, 2005; Phan, 2010; Schurtz, 2009) koji upućuju na neke od značajnih prednosti primjene kritičkog mišljenja u nastavnom procesu. Kritičko mišljenje kao vještina koja zahtijeva primjenu složenih misaonih procesa pospješuje sveukupnu kvalitetu učenja i poučavanja u nastavi. Ono kod učenika potiče dubinsko razumijevanje nastavnog sadržaja te procesuiranje informacija na metakognitivnoj razini. Učenicima pomaže da lakše prate nastavni sadržaj kojeg uglavnom odlikuje velika količina informacija s kojima se najčešće prvi puta susreću i za čije je usvajanje potreban značajan kognitivni napor. Kritičko mišljenje od učenika zahtijeva samostalnost u donošenju zaključaka i prevladavanje nastavnih situacija u kojima nastavnik učenicima pruža već gotove zaključke, što dovodi do težeg zaboravljanja postignutog znanja. Također, kritičko mišljenje učenike potiče na samoevaluaciju procesa učenja, pospješuje razvoj samoreguliranog učenja i pomaže im kritički vrednovati sadržaj učenja.

U obrazovnoj praksi učenicima predstavlja teškoću nedostatak sposobnosti prepoznavanja i izdvajanja relevantnih informacija iz tekstova koji se koriste u nastavi (Oliveras, 2011). Budući da spomenuto obuhvaća neke od ključnih vještina kritičkog mišljenja, njegovom se primjenom nedvojbeno pospješuje nastava u kojoj se može primijeniti rad na tekstu. S druge strane, kritičko mišljenje stimulira i intelektualne procese poput primjene apstraktnog znanja na konkretnom zadatku koji imaju nezaobilaznu ulogu u nastavi matematike, kemije ili fizike. $\mathrm{Na}$ ovome je području indikativni rezultat istraživanja Andersona i Reida (2013) koji su proučavali jesu li vještine kritičkog mišljenja prenosive unutar različitih nastavnih predmeta. Došli su do rezultata da se vještine kritičkog mišljenja mogu uspješno transferirati iz jednog nastavnog predmeta u drugi. Štoviše, sudionici su naveli da su ove vještine uspješno počeli primjenjivati i u svakodnevnom životu izvan učionice. Autori 
zaključuju kako upravo tome teže i suvremeni koncepti odgojno-obrazovne prakse. ${ }^{3}$

\subsection{Kritičko mišljenje u obrazovanju: pregled dosadašnjih istraživanja u hrvatskom kontekstu}

Promatrajući hrvatski istraživački prostor može se uočiti kako su istraživanja o kritičkom mišljenju uopće, pa tako i o kritičkom mišljenju u obrazovanju, rijetka što upućuje na potrebu stimuliranja takvih istraživanja. Radovi domaćih suvremenih autora koji se bave kritičkim mišljenjem (Bjelanović Dijanić, 2012; Grozdanić, 2009; Majdak i Ajduković, 2003; Miliša i Ćurko, 2010; Nikčević-Milković, 2004; Zagorac, 2012) uglavnom predstavljaju teorijske prikaze rasprava o konceptu kritičkog mišljenja u društvenom, znanstvenom i obrazovnom kontekstu te prikaze poučavanja temeljenih na aktivnostima u nastavi koje potiču razvoj kritičkog mišljenja učenika. U navedenim se radovima jednoglasno ističe kako je kritičko mišljenje važan dio suvremenog obrazovanja te da poučavanje kritičkog mišljenja predstavlja neophodan cilj kojemu je potrebno težiti u nastavnoj praksi što uvjetuje i potrebu za promjenom postojećeg konteksta učenja i poučavanja.

U razmatranjima domaćih autora koji sagledavaju odnos kritičkog mišljenja i obrazovanja primjećuje se njihova usuglašenost oko uloge nastavnika kao ključnog facilitatora nastavnog okruženja koje će pogodovati i biti usmjereno na poučavanje za kritičko mišljenje. Navodi se kako je potrebno da nastavnici budu osposobljeni za korištenje određenih nastavnih metoda te primjenu nastavnih aktivnosti kojima se razvija kritičko mišljenje učenika, s obzirom da poučavanje za kritičko mišljenje zahtijeva visoki angažman i profesionalnu kompetentnost nastavnika (Bošnjak, 2009; Majdak i Ajduković, 2003; Miliša i Ćurko, 2010). Značajan doprinos literaturi koja se bavi problematikom kritičkog mišljenja u suvremenom odgojno-obrazovnom kontekstu te poučavanju vještinama kritičkog mišljenja i njegovoj primjeni dale su Buchberger (2012) i Žigo (2015). Vrijednost ove literature u prvome se redu očituje u tome što, osim teorijskih razmatranja koncepta kritičkog mišljenja kojima je usmjerena većina radova hrvatskih autora, autorice su raspravi o kritičkom mišljenju dale i praktičnu dimenziju.

\footnotetext{
${ }^{3}$ Istraživanje Andersona i Reida (2013) vezano je uz nacionalni kontekst Sjedinjenih Američkih Država.
} 
Od empirijskih istraživanja kritičkog mišljenja u obrazovanju u domaćem istraživačkom prostoru mogu se izdvojiti svega dva. Kvaščev (1969) je ispitivao povezanost kritičkog mišljenja i procesa učenja kod učenika. Istraživanjem je utvrđeno kako kritičko mišljenje daje značajan doprinos pri izboru metoda učenja te pomaže učenicima pri izvođenju zaključaka i pronalaženju zajedničke osnove informacija prezentiranih u sadržaju poučavanja. Kritičko mišljenje također pomaže učenicima i pri procjeni znanstvene vjerodostojnosti sadržaja poučavanja te njegove primjene u različitim situacijama. Istaknuto ukazuje na činjenicu kako kritičko mišljenje pomaže učenicima da razviju interdisciplinaran pristup sadržaju te mu pridaju višestruku uporabnu vrijednost. Isto tako, kritičko mišljenje pridonosi višim razinama usvojenosti obrazovnih sadržaja što potiče učenike na osmišljavanje vlastitih primjera i interpretaciju sadržaja poučavanja vlastitim riječima, a ne isključivo njegovu reprodukciju. Usporedbom pozitivnih ishoda primjene kritičkog mišljenja u procesu obrazovanja koje ističe Kvaščev (1969) u odnosu na one koje ističu prethodno spomenuti strani autori (Paul, 2005; Bassham et al., 2008; Phan, 2010; Da Silva Almeida i Rodrigues Franco, 2011) primjetno je da se izdvajaju neki zajednički elementi poput poticanja samoreguliranog učenja, uspješnijeg usvajanja sadržaja poučavanja na višim razinama te povećanje sveukupne kvalitete procesa učenja i poučavanja.

Bošnjak (2009) je proveo pilot istraživanje sa ciljem utvrđivanja u kolikoj su mjeri kritičko mišljenje i konstruktivističko poučavanje primjenjivi na nastavu sociologije u srednjim strukovnim školama i gimnazijama. U svrhu istraživanja osmišljen je nastavni sat koji se temeljio na konstruktivističkim principima poučavanja gdje se, između ostalog, ispitivalo prihvaćanje dimenzija kritičkog mišljenja od strane učenika. Spomenute dimenzije odnosile su se na razvoj dispozicija spram kritičkog mišljenja, vještine kritičkog mišljenja, prenosivost vještina i metakognitivno praćenje. Pritom se kritičko mišljenje koristilo kao »kontrolni koncept « u svrhu pokazivanja u kojoj mjeri konstruktivističko poučavanje može zadovoljiti kriterije mišljenja višeg reda kakvo je kritičko mišljenje. Istraživanjem se utvrdilo kako su učenici dimenzije kritičkog mišljenja najviše prihvatili na uvodnoj, dispozicijskoj razini, dok je prihvaćanje prema metakognitivnom praćenju kumulativno opadalo. Nadalje, utvrđena je i povezanost te komplementarnost kritičkog mišljenja s konstruktivističkim poučavanjem na razinama planiranja i izvedbe nastave. Konačno, rezultati istraživanja pokazali su kako je kritičko mišljenje i konstruktivističko poučavanje primjenjivo u okviru 
nastave sociologije koje, uz određene preinake, može biti sastavnim dijelom planiranja i programiranja u postojećoj nastavnoj praksi.

\section{Umjesto zaključka: otvoreni smjerovi budućih istraživanja poučavanja za kritičko mišljenje}

Na temelju prikazanih teorijskih razmatranja i određenja koncepta kritičkog mišljenja te indikativnih nalaza dosadašnjih istraživanja kritičkog mišljenja u obrazovanju, uz uvažavanje temeljnih didaktičko-metodičkih elemenata nastave, kao teorijska podloga za provođenje budućih istraživanja toga područja u nastavku teksta razrađuje se konstrukt poučavanja za kritičko mišljenje. Prvo, konstrukt poučavanja za kritičko mišljenje razrađuje se kroz identificiranje kategorija prema kojima se određena dimenzija poučavanja za kritičko mišljenje može promatrati: obilježja nastavnika; pristupi poučavanju; nastavne metode i oblici rada; razredno-nastavno okruženje; i (samo)evaluacija. Drugo, konstrukt poučavanja za kritičko mišljenje razrađuje se i kroz dodatnu operacionalizaciju svake istaknute kategorije uz navođenje dimenzije kojoj pripada (Tablica 4).

Tablica 4. Kategorizacija i operacionalizacija poučavanja kritičkog mišljenja

\begin{tabular}{|l|l|}
\hline \multicolumn{2}{|c|}{ POUČAVANJE ZA KRITIČKO MIŠLJENJE } \\
\hline \multicolumn{2}{|c|}{ Obilježja nastavnika } \\
\hline Kategorija i pripadajuće dimenzije & \multicolumn{1}{|c|}{ Operacionalizacija } \\
\hline $\begin{array}{l}\text { Obilježja nastavnika: stav prema kri- } \\
\text { tičkom mišljenju }\end{array}$ & $\begin{array}{l}\text { Nastavnici percipiraju kritičko mišljenje kao } \\
\text { primarni cilj nastave; imaju razvijen stav o } \\
\text { važnosti razvoja vještina kritičkog mišljenja } \\
\text { učenika. }\end{array}$ \\
\hline $\begin{array}{l}\text { Obilježja nastavnika: kompetencije } \\
\text { kritičkog mišljenja nastavnika }\end{array}$ & $\begin{array}{l}\text { Nastavnici posjeduju znanja o kritičkom mi- } \\
\text { šljenju i načinima njegove implementacije u } \\
\text { nastavu; osposobljeni su za primjenu nastav- } \\
\text { nih metoda i oblika rada kojima se razvija kri- } \\
\text { tičko mišljenje učenika. }\end{array}$ \\
\hline $\begin{array}{l}\text { Obilježja nastavnika: stil mišljenja } \\
\text { nastavnika }\end{array}$ & $\begin{array}{l}\text { Nastavnici iskazuju tendenciju prema organi- } \\
\text { zaciji, planiranju i istraživanju; iskazuju želju } \\
\text { za učenjem i stjecanjem znanja bez određenih } \\
\text { očekivanja; uvažavaju i vrednuju različitost u } \\
\text { razmišljanjima učenika; otvoreni su ka novim } \\
\text { idejama. }\end{array}$ \\
\hline Prostor za daljnju razradu kategorije obilježja nastavnika.
\end{tabular}




\begin{tabular}{|c|c|}
\hline \multicolumn{2}{|c|}{ Pristupi poučavanju } \\
\hline Kategorija i pripadajuće dimenzije & Operacionalizacija \\
\hline $\begin{array}{l}\text { Pristupi poučavanju: izravno pouča- } \\
\text { vanje kritičkom mišljenju }\end{array}$ & $\begin{array}{l}\text { Nastavnici učenike izravno poučavaju kritič- } \\
\text { kom mišljenju (putem zasebnih programa; na- } \\
\text { stavnih predmeta kritičkog mišljenja; nastav- } \\
\text { nih cjelina i jedinica). }\end{array}$ \\
\hline $\begin{array}{l}\text { Pristupi poučavanju: implicitno po- } \\
\text { učavanje kritičkom mišljenju }\end{array}$ & $\begin{array}{l}\text { Nastavnici učenike implicitno poučavaju kri- } \\
\text { tičkom mišljenju kroz njegovu primjenu u } \\
\text { nastavi bez da o kritičkom mišljenju izravno } \\
\text { govore učenicima. }\end{array}$ \\
\hline $\begin{array}{l}\text { Pristupi poučavanju: ishodi učenja } \\
\text { viših razina postignuća }\end{array}$ & $\begin{array}{l}\text { Nastavnici svoje poučavanje temelje na isho- } \\
\text { dima učenja kojima se ostvaruju više razine } \\
\text { postignuća (primjena, analiza, vrednovanje, } \\
\text { stvaranje). }\end{array}$ \\
\hline \multicolumn{2}{|c|}{ Prostor za daljnju razradu kategorije pristupi poučavanju. } \\
\hline \multicolumn{2}{|c|}{ Nastavni sadržaj } \\
\hline Kategorija i pripadajuće dimenzije & Operacionalizacija \\
\hline $\begin{array}{l}\text { Nastavni sadržaj: razumijevanje i in- } \\
\text { terpretacija }\end{array}$ & $\begin{array}{l}\text { Nastavnici potiču učenike na objašnjavanje } \\
\text { nastavnog sadržaja vlastitim riječima; potiču } \\
\text { učenike na navođenje primjera pri interpreta- } \\
\text { ciji nastavnog sadržaja. }\end{array}$ \\
\hline Nastavni sadržaj: analiza & $\begin{array}{l}\text { Nastavnici prezentiraju nastavni sadržaj uče- } \\
\text { nicima jasnim razlikovanjem i isticanjem rele- } \\
\text { vantnih i irelevantnih informacija; poučavaju } \\
\text { prepoznavanju argumenata i razloga na teme- } \\
\text { lju kojih su formirani. }\end{array}$ \\
\hline Nastavni sadržaj: vrednovanje & $\begin{array}{l}\text { Nastavnici potiču učenike na vrednovanje in- } \\
\text { formacija i gledišta; potiču učenike na propiti- } \\
\text { vanje pretpostavki iz kojih proizlaze određene } \\
\text { informacije. }\end{array}$ \\
\hline $\begin{array}{l}\text { Nastavni sadržaj: uspoređivanje i ge- } \\
\text { neriranje prigovora (međupredmetna } \\
\text { korelacija) }\end{array}$ & $\begin{array}{l}\text { Nastavnici povezuju nastavni sadržaj svoga } \\
\text { nastavnog predmeta s nastavnim sadržajem } \\
\text { ostalih nastavnih predmeta. }\end{array}$ \\
\hline $\begin{array}{l}\text { Nastavni sadržaj: uspoređivanje i ge- } \\
\text { neriranje prigovora }\end{array}$ & $\begin{array}{l}\text { Nastavnicipotičuučenike da povezuju prethod- } \\
\text { no stečena znanja u usvajanju novih; prezenti- } \\
\text { raju nastavni sadržaj iz različitih perspektiva. }\end{array}$ \\
\hline $\begin{array}{l}\text { Nastavni sadržaj: razvoj zauzimanja } \\
\text { stavova }\end{array}$ & $\begin{array}{l}\text { Nastavnici potiču formiranje i argumentiranje } \\
\text { stavova učenika o nastavnom sadržaju. }\end{array}$ \\
\hline Prostor za daljnju razradu kategorij & nastavni sadržaj. \\
\hline
\end{tabular}




\begin{tabular}{|c|c|}
\hline \multicolumn{2}{|c|}{ Nastavne metode i oblici rada } \\
\hline Kategorija i pripadajuće dimenzije & Operacionalizacija \\
\hline $\begin{array}{l}\text { Nastavne metode i oblici rada: primje- } \\
\text { na aktivnih nastavih metoda }\end{array}$ & $\begin{array}{l}\text { Nastavnici primjenjuju različite aktivne na- } \\
\text { stavne metode u nastavi (diskusija, insert meto- } \\
\text { da, kockarenje, i sl.); primjenjuju suradničke } \\
\text { oblike rada u nastavi (rad u paru, grupni rad, } \\
\text { timski rad). }\end{array}$ \\
\hline \multicolumn{2}{|c|}{ Prostor za daljnju razradu kategorije nastavne metode i oblici rada. } \\
\hline \multicolumn{2}{|c|}{ Razredno-nastavno okružje } \\
\hline Kategorija i pripadajuće dimenzije & Operacionalizacija \\
\hline $\begin{array}{l}\text { Razredno-nastavno okruženje: podr- } \\
\text { Žavajuće i tolerantno }\end{array}$ & $\begin{array}{l}\text { Nastavnici razvijaju podržavajuće i tolerantno } \\
\text { razredno-nastavno okruženje; učenici slobod- } \\
\text { no izražavaju vlastita mišljenja na nastavi. }\end{array}$ \\
\hline \multicolumn{2}{|c|}{ Prostor za daljnju razradu kategorije razredno-nastavno okružje. } \\
\hline \multicolumn{2}{|c|}{ (Samo)evaluacija } \\
\hline Kategorija i pripadajuće dimenzije & Operacionalizacija \\
\hline $\begin{array}{l}\text { (Samo)evaluacija: procjenjivanje } \\
\text { esejskim tipovima zadataka }\end{array}$ & $\begin{array}{l}\text { Nastavnici procjenjuju učenička postignuća } \\
\text { esejskim tipovima zadataka. }\end{array}$ \\
\hline $\begin{array}{l}\text { (Samo)evaluacija: samoregulirano } \\
\text { učenje }\end{array}$ & $\begin{array}{l}\text { Nastavnici potiču učenike na planiranje i pra- } \\
\text { ćenje vlastitog učenja. }\end{array}$ \\
\hline $\begin{array}{l}\text { (Samo)evaluacija: refleksija o vlasti- } \\
\text { tom radu i postignućima (učenici) }\end{array}$ & $\begin{array}{l}\text { Nastavnici potiču učenike na refleksiju o vlas- } \\
\text { titom radu i ostvarenim postignućima u nasta- } \\
\text { vi. }\end{array}$ \\
\hline $\begin{array}{l}\text { (Samo)evaluacija: refleksija o vlasti- } \\
\text { tom radu i postignućima (nastavnici) }\end{array}$ & $\begin{array}{l}\text { Nastavnici redovito vrednuju vlastiti rad i pro- } \\
\text { mišljaju o nastavi. }\end{array}$ \\
\hline Prostor za daljnju razradu kategorije & razredno-nastavno okružje. \\
\hline
\end{tabular}

Prikazana operacionalizacija konstrukta poučavanja za kritičko mišljenje nastala na temelju analize i razrade dosadašnjih istraživanja može poslužiti kao teorijska podloga $\mathrm{i}$ inovativni pravac budućih istraživanja. Koristeći predloženu operacionalizaciju konstrukta poučavanja za kritičko mišljenje moguće je ispitati intenzitet primjene pojedinih kategorija i dimenzija poučavanja za kritičko mišljenje u obrazovnoj praksi. Vrijedilo bi doznati koje se kategorije i dimenzije u obrazovnoj praksi intenzivnije primjenjuju, koje kategorije nastavnika ih intenzivnije primjenjuju te u kojim predmetima, područjima ili razinama obrazovnog sustava se intenzivnije primjenjuju. Budući da je viši stupanj primjene ujedno i pokazatelj poželjne prakse, takvo bi ispitivanje pru- 
žilo jasne smjernice za osmišljavanje optimalnih načina jačanja kapaciteta nastavnika za poučavanje kritičkog mišljenja. Osim identificiranih istaknutih kategorija i dimenzija poučavanja za kritičko mišljenje, ostaje prostor i za daljnju elaboraciju toga područja kako postojećim tako i novoformiranim kategorijama. Primjerice, daljnja elaboracija može ići u smjeru ispitivanja dodatnih vještina i obilježja nastavnika važnih za uspješnu implementaciju poučavanja za kritičko mišljenje, određenih obilježja učenika koja se mogu povezati s poučavanjem za kritičko mišljenje te primjerenosti kreiranih modela poučavanja kritičkog mišljenja određenim nastavnim predmetima ili skupinama nastavnih predmeta. Uvažavanjem složenosti i zahtjevnosti poučavanja za kritičko mišljenje ostaje za istražiti i povezanost poučavanja za kritičko mišljenje i boljih postignuća učenika, kao i ostalih čimbenika učinkovite škole kao ključnog istraživačkog pitanja suvremenog obrazovanja. Doprinos takvih istraživanja za razvoj obrazovanja u tom je slučaju razvidan, no istinski se doprinos događa onda kada se nalazi iz takvih istraživanja zaista primjene u praksi i to suradničkim radom svih dionika obrazovanja - od istraživača i kreatora obrazovnih politika, nastavnika, stručnih suradnika i ravnatelja, do roditelja i učenika.

\section{Literatura}

Ahern, Aoife; McNamara, Martin; McRuairc, Gerry i O'Connor, Tom (2012), "Critical thinking in the university curriculum - the impact on engineering education «, European Journal on Engineering Education, 37(2), str. 125132. doi: https://doi.org/10.1080/03043797.2012.666516

Alwehaibi, Huda Umar (2012), »Novel program to promote critical thinking among higher education students: empirical study from Saudi Arabia«, Asian Social Science, 8(2), str. 193-204. doi: http://dx.doi.org/10.5539/ass.v8n11p193

Anderson, Phillys R. i Reid, Joanne R. (2013), »The effect of critical thinking instruction on graduates of a college of business administration «, Journal of Higher Education Theory and Practice, 13(3/4), str. 149-167.

Anderson,Lorin W.iKrathwohl,DavidR.(2001), A Taxonomyfor Learning, Teaching and Assessing: Revision of Bloom's Taxonomy of Educational Objectives, New York: Longman.

Bahr, Nan (2010), »Thinking critically about critical thinking in higher education«, International Journal for the Scholarship of Teaching and Learning, 4(2), str. 1-16. doi: https://doi.org/10.20429/ijsotl.2010.040209 
Bjelanović Dijanić, Željka (2012), »Neke metode za razvoj kritičkog mišljenja učenika po ERR sustavu«, Metodički ogledi, 19(1), str. 163-179.

Boonjeam, Waraporn; Tesaputa, Kowat i Sri-ampai, Anan (2017), »Program development for primary school teachers' critical thinking «, International Education Studies, 10(2), str. 131-138. doi: https://doi.org/10.5539/ies.v10n2p131

Bošnjak, Zvonimir (2009), »Primjena konstruktivističkog poučavanja i kritičkog mišljenja u srednjoškolskoj nastavi sociologije: pilot istraživanje«, Revija za sociologiju, 40(3-4), str. 257-277.

Buchberger, Iva (2012), Kritičko mišljenje: priručnik kritičkog mišljenja, slušanja, čitanja i pisanja, Rijeka: Universitas.

Chee, Choy S. i San Oo, Pou (2012), »Reflective thinking and teaching practices: a precursor for incorporating critical thinking into the classroom? «, International Journal of Instruction, 5(1), str. 167-182.

[CEU] Council of the European Union (2016), Developing media literacy and critical thinking through education and training - Council conclusions. Dostupno na:

http://data.consilium.europa.eu/doc/document/ST-9641-2016-INIT/en/pdf [24. 4. 2017.]

[CEU] Council of the European Union (2015), Declaration on promoting citizenship and the common values of freedom, tolerance and non-discrimination through education. Dostupno na: http://ec.europa.eu/dgs/education_culture/ repository/education/news/2015/documents/citizenship-education-declaration_en.pdf [24.4.2017.]

Dewey, John (2012), How We Think?, Boston, New York, Chicago: D. C. Heath \& CO., Publishers.

Emir, Serap (2013), »Contributions of teachers' thinking styles to critical thinking dispositions (Istanbul-Fatih sample)«, Educational Sciences: Theory and Practice, 13(1), str. 337-347.

Ennis, Robert H. (2011), »The Nature of Critical Thinking: An Outline of Critical Thinking Dispositions and Abilities«. Dostupno na: http://faculty.education. illinois.edu/rhennis/documents/TheNatureofCriticalThinking_51711_000. pdf [17. 3. 2017.]

[EC] European Commission; EACEA i Eurydice (2016), Promoting citizenship and the common values of freedom, tolerance and non-discrimination through education: Overview of education policy developments in Europe following the Paris Declaration of 17 March 2015, Luxembourg: Publications Office of the European Union. doi: https://doi.org/10.2797/396908

Facione, Peter A. (1990), »Critical thinking: a statement of expert consensus for purposes of educational assessment and instruction«. Dostupno na: https:// www.researchgate.net/profile/Peter_Facione/publication/242279575_Critical_Thinking_A_Statement_of_Expert_Consensus_for_Purposes_of_Edu- 
cational_Assessment_and_Instruction/links/5849b94508ae82313e7108de/ Critical-Thinking-A-Statement-of-Expert-Consensus-for-Purposes-of-Educational-Assessment-and-Instruction.pdf [14. 3. 2017.]

Facione, Peter A.; Giancarlo, Carol A.; Facione, Noreen C. i Gainen, Joanne (1995), »The disposition toward critical thinking«, Journal of General Education, 44(1), str. 1-25.

Fung, Dennis (2014), »Promoting critical thinking through effective group work: A teaching intervention for Hong Kong primary school students «, International Journal of Educational Research, 66(1), str. 45-62. doi:

http://dx.doi.org/10.1016/j.ijer.2014.02.002

Grozdanić, Višnja (2009), »Poučavanje i evaluacija kritičkog mišljenja«, Napredak, 150(3-4), str. 380-424.

Gyeong, Ju An i Myung, Sook Yoo (2008), »Critical thinking and learning styles of nursing students at the Baccalaureate nursing program in Korea , Contemporary nurse: a journal for the Australian nursing profession, 29(1), str. 100-109. doi: https://doi.org/10.5172/conu.673.29.1.100

Hoidin, Sabine i Kärkkäinen, Kiira (2014), »Promoting skills for innovation in higher education: A literature review on the effectiveness of problem-based learning and of teaching behaviours«, OECD Education Working Papers, No. 100, Paris: OECD Publishing. doi: http://dx.doi.org/10.1787/5k3tsj671226-en

Innabi, Hanan (2003), »Aspects of critical thinking in classroom instruction of secondary school mathematics teachers in Jordan «. Dostupno na: http://dipmat.math.unipa.it/ grim/21_project/21_brno03_Innabi.pdf [25. 3. 2017.]

Kärkkäinen, Kiira (2012), »Bringing about curriculum innovations: Implicit approaches in the OECD area«, OECD Education Working Papers, No. 82, Paris: OECD Publishing. doi: http://dx.doi.org/10.1787/5k95qw8xzl8s-en

Klooster, David (2002), »Što je kritičko mišljenje?«, Metodički ogledi, 9(2), str. $87-95$.

Kvaščev, Radivoj (1969), Razvijanje kritičkog mišljenja kod učenika: priručnik za nastavnike, Beograd: Zavod za izdavanje udžbenika Socijalističke Republike Srbije.

Lewine, Rich; Sommers, Alison; Waford, Rachel i Robertson, Catherine (2015), »Setting the mood for critical thinking in the classroom «, International Journal for the Scholarship of Teaching and Learning, 9(2), str. 1-4.

doi: https://doi.org/10.20429/ijsotl.2015.090205

Lipman, Matthew (2003), Thinking in Education, Cambridge: Cambridge University Press.

Majdak, Marijana i Ajduković, Marina (2003), »Kako pripremiti studente socijalnog rada za kritičko mišljenje i djelovanje u području maloljetničke delinkvencije«, Ljetopis socijalnog rada, 10(1), str. 71-88. 
Marin, Lisa M. i Halpern, Diane F. (2011), »Pedagogy for developing critical thinking in adolescents: Explicit instruction produces greatest gains«, Thinking Skills and Creativity, 6(1), str. 1-13.

doi: https://doi.org/10.1016/j.tsc.2010.08.002

Miliša, Zlatko i Ćurko, Bruno (2010), »Odgoj za kritičko mišljenje i medijska manipulacija «, MediAnali, 4(7), str. 57-72.

Moeti, Bakadzi; Mgawi, Rabson K. i Smitta Moalosi, Waitshega T. (2017), »Critical thinking among post-graduate diploma in education students in higher education: Reality or fuss?«, Journal of Education and Learning, 6(2), str. 13-24. doi: https://doi.org/10.5539/jel.v6n2p13

[MZOS] Ministarstvo znanosti, obrazovanja i sporta (2015), Strategija obrazovanja, znanosti i tehnologije, Zagreb: Ministarstvo znanosti, obrazovanja i sporta.

Nikčević-Milković, Anela (2004), »Aktivno učenje na visokoškolskoj razini«, Život i škola, 12(2), str. 47-54.

Ordem, Eser (2017), »Developing critical-thinking dispositions in a listening/ speaking class «, English Language Teaching, 10(1), str. 50-55.

doi: https://doi.org/10.5539/elt.v10n1p50

Pešić, Jelena (2003), »Kritičko mišljenje između pomodarstva i promišljanja: ka teorijskom utemeljenju koncepta«, Psihologija, 36(4), str. 411-423.

Piergiovanni, Polly R. (2014), »Creating a critical thinker«, College Teaching, 62(3), str. 86-93. doi: https://doi.org/10.1080/87567555.2014.896775

Razaei, Saeed; Derakshan, Ali i Bagherkazemi, Marzieh (2011), „Critical thinking in language education«, Journal of Language Teaching and Research, 2(4), str. 769-777. doi: https://doi.org/10.4304/j1tr.2.4.769-777

Shim, Woo-jeong i Walczak, Kelley (2012), »The impact of faculty teaching practices on the development of students' critical thinking skills«, International Journal of Teaching and Learning in Higher Education, 24(1), str. 16-30.

Tiruneh, Dawit T., Verburgh, An. i Elen, Jan (2014), »Effectiveness of critical thinking instruction in higher education: A systematic review of intervention studies«, Higher Education Studies, 4(1), str. 1-17.

doi: https://doi.org/10.5539/hes.v4n1p1

UNESCO (2016), Youth Day at Global MIL Week: Critical thinking in focus. Dostupno na:

http://en.unesco.org/news/youth-day-global-mil-week-critical-thinking-focus [24. 4. 2017.]

UNICEF (2000), Life Skills: A Facilitators Guide for Teenagers. Dostupno na: https://www.unicef.org/eapro/Life_Skills_A_facilitator_guide_for_teenagers.pdf [24. 4. 2017.] 
Wallace, Elise D. i Jefferson, Renee N. (2015), »Developing critical thinking skills: assessing the effectiveness of workbook exercises«, Journal of College Teaching and Learning, 12(2), str. 101-108.

doi: https://doi.org/10.19030/tlc.v12i2.9187

Warburton, Edward i Toff, Bruce (2005), »The effect of perceived learner advantages on teachers' beliefs about critical-thinking activities«, Journal of Teacher Education, 56(1), str. 24-33.

Zagorac, Ivana (2012), »Kritičko mišljenje i bioetika«, JAHR - European Journal of Bioethics, 3(5), str. 69-80.

Žigo, Iva Rosanda (2015), (S)misao kritike, Koprivnica: Sveučilište Sjever.

\title{
CRITICAL THINKING IN EDUCATION: CONTRIBUTIONS AND POSSIBLE DIRECTIONS
}

\author{
Iva Buchberger, Valentina Bolčević, Vesna Kovač
}

This paper presents and discusses previous research on critical thinking in education. The aim of the proposed conference paper is to develop a theoretical framework and identify innovative directions for future research on the basis of previous research analyses of critical thinking in education. The paper includes a review and commentary on critical thinking concepts and previous research within the context of Croatian and international research. The results of previous research show the importance of developing and implementing teaching for critical thinking, as it increases the quality of the learning and teaching. Research shows that the teacher plays an important role in stimulating pupils' critical thinking, foremost by applying active learning and teaching methods. In the conclusion, on the basis of the definition of the concept of critical thinking and a review of current research, a construct for teaching critical thinking is developed through its categorization and operationalization, which also presents a possible direction for future research.

Key words: critical thinking, education, teachers, teaching for critical thinking, pupils 